\title{
Doses and Application Seasons of Potassium in the Soybean-Corn Succession in Soil With Improved Fertility in the Southwest of Goiás
}

\author{
Warlles Domingos Xavier ${ }^{1}$, Leandro Flávio Carneiro ${ }^{2}$, Claudinei Martins Guimarães ${ }^{3}$, João Vitor de Souza Silva ${ }^{1}$, \\ Flávio Araújo Pinto ${ }^{2}$, Diego Oliveira Ribeiro ${ }^{1}$, Vinicius Silva Sousa ${ }^{4} \&$ Álvaro Vilela de Resende ${ }^{5}$ \\ ${ }^{1}$ Goiano Federal Institute, Rio Verde, Goiás, Brazil \\ ${ }^{2}$ São João Del-Rei Federal University, Sete Lagoas, Minas Gerais, Brazil \\ ${ }^{3}$ Viçosa Federal University, Viçosa, Minas Gerais, Brazil \\ ${ }^{4}$ Goiás Federal University, Goiânia, Goiás, Brazil \\ ${ }^{5}$ Brazilian Agricultural Research Corporation, Embrapa Milho e Sorgo, Sete Lagoas, Minas Gerais, Brazil \\ Correspondence: Warlles Domingos Xavier, Soil Science Department, IF Goiano, Goiano Federal Institute, \\ 75.901-970, Rio Verde, GO, Brazil. Tel: 55-066-99971-1333. E-mail: warlles.pesquisa@gmail.com
}

Received: November 24, 2018

doi:10.5539/jas.v11n4p307

\author{
Accepted: January 22, 2019 Online Published: March 15, 2019
}

URL: https://doi.org/10.5539/jas.v11n4p307

\begin{abstract}
Soils with improved fertility indicate opportunities for more rational use of fertilizers. The objective of this study was to evaluate the management of potassium fertilization in the succession of soybean-corn in soil with improved fertility, in the southwestern region of the state, Goiás. The experiment was set in $5 \times 3$ factorial scheme, arranged in randomized blocks with four repetitions. The treatments consisted of the combination of potassium doses $\left(0,40,80,120\right.$ and $160 \mathrm{~kg} \mathrm{ha}^{-1}$ of $\left.\mathrm{K}_{2} \mathrm{O}\right)$ and seasons of application $(100 \%$ of the dose in pre-planting, $100 \%$ of the dose in coverage and in installments with $50 \%$ of the dose in pre-planting $+50 \%$ in coverage). The best performance of soybean, considering grain yield, was obtained with the parceled application of $80 \mathrm{~kg} \mathrm{ha}^{-1}$ of $\mathrm{K}_{2} \mathrm{O}$, with production of $3.6 \mathrm{Mg} \mathrm{ha}^{-1}$. The highest corn production was obtained with the anticipated application of $160 \mathrm{~kg} \mathrm{ha}^{-1}$ of $\mathrm{K}_{2} \mathrm{O}$ in soybean. In the management of potassium fertilization in improved fertility soil in the soybean-corn succession, the parceled application of $120 \mathrm{~kg} \mathrm{ha}^{-1}$ of $\mathrm{K}_{2} \mathrm{O}$ kept the available $\mathrm{K}$ reserve in the soil constant when compared to its initial content.
\end{abstract}

Keywords: grain yield, nutrient cycling, no-tillage, residual effect, system fertilization, Glycine max

\section{Introduction}

The soybean production chain (Glycine max (L.) Merrill) is one of the most important economic segments of Brazilian agribusiness (CONAB, 2017). Considering primary production alone, soybean accounts for about $51.8 \%$ of national grain production (USDA, 2016). However, much of their success is related to the incorporation of technology in the production process, among which stands out the no-tillage system, which is the seeding process without soil disturbance, straw maintenance and rotation of cultures.

In this way, the cultivation of earlier soybean varieties opened the opportunity for the cultivation of a second crop, common in the Cerrado region (Guareschi et al., 2008). Among the main species used in rotation and succession are corn (Zea mays), which, as a little harvest, has consolidated itself in recent years by the significant increase of $63.5 \%$ in planted area and, also, $36.5 \%$ in productivity, consolidating the no-tillage system in the soybean-corn succession (Pauletti et al., 2010). Thus, soybean and corn together account for $87.13 \%$ of total grain production in Brazil (CONAB, 2016a).

However, occupation programs have led to the development of an agriculture that uses high levels of agricultural supplies, with nutrient application greater than the quantities exported in the crops, aiming to gradually improve soil fertility. As a consequence, after few years the fertility level of these soils increased, presenting levels of phosphorus (P) and potassium (K) above critical, called "improved fertility soils" (Sousa \& Lobato, 2004), indicating opportunities for better planning of fertilization or a more rational use of fertilizers.

Concomitantly to the high nutrient levels in these soils, the management of fertilization in improved fertility areas, must consider the remaining nutrient content of previous crops in the soil and in the straws crop that 
together make the production system which influences the amount of fertilizers to be applied to the crops (Resende et al., 2012).

Despite the reduced diversity, this simple alternation of species brings important benefits to the system of grain production, notably the nitrogen input of soybean residues from soybean to corn and straw production of corn, which is more resistant to decay, besides the cycling of nutrients, especially $\mathrm{K}$. According to Calonego et al. (2012), at 135 days after cutting, there was a $42 \%$ reduction of dry matter straw and corn release of $41 \% \mathrm{~N}, 35 \%$ $\mathrm{P}$ and $60 \% \mathrm{~K}$. Foloni and Rosolem (2008) demonstrated that the soybean crop had potassium utilization applied to millet cultivated as cover crop before soybean.

Fancelli and Tsumanuma (2006) show high amounts of K extracted by the corn average of $20.4 \mathrm{~kg}$ for each ton of produced grains contributing to significantly reduced levels of $\mathrm{K}$ in the soil after cultivation, however, $\mathrm{K}$ exported in the grains corresponds only to $19 \%$ of the cumulative total in the aerial part and the remainder can be utilized by the planted crop in succession, in the case of soybean.

Given this scenario, it is necessary to carry out studies on management strategies that may increase the efficiency of the use of fertilizer considering the pre-existing fertility in the soil. Thus, the aim of this work was to evaluate the management of potassium fertilization in soybean-corn succession in soil of improved fertility under no-tillage system.

\section{Material and Methods}

The present study was carried out in a rural property in the county of Jataí, Southwest region of the state of Goiás, in the Cerrado biome. The climate of the region is predominantly tropical, with an annual average temperature of $22{ }^{\circ} \mathrm{C}$ and average annual precipitation ranging from 1,650 to $1,800 \mathrm{~mm}$. The soil in the area is classified as in a clayey Oxisol from Cerrado with high fertility (Santos et al., 2013).

The soil analysis before the implantation of the experiment showed clay content $=62 \%$ and $64 \%, \mathrm{pH} \mathrm{CaCl}_{2}=$ 5.3 and 4.9; $\mathrm{P}\left(\right.$ Mehlich 1) $=12.4$ and $2.4 \mathrm{mg} \mathrm{dm}^{-3} ; \mathrm{K}$ (Mehlich 1) $=71$ and $45 \mathrm{mg} \mathrm{dm}^{-3} ; \mathrm{Ca}=3.4$ and $1.2 \mathrm{cmol}_{\mathrm{c}}$ $\mathrm{dm}^{-3} ; \mathrm{Mg}=0.5$ and $0.2 \mathrm{cmol}_{\mathrm{c}} \mathrm{dm}^{-3} ; \mathrm{Al}=0.1$ and $0.2 \mathrm{cmol}_{\mathrm{c}} \mathrm{dm}^{-3} ; \mathrm{H}+\mathrm{Al}=5.8$ and $5.6 \mathrm{cmol}_{\mathrm{c}} \mathrm{dm}^{-3} ; \mathrm{CTC}=8.8$ and $7.1 \mathrm{cmol}_{\mathrm{c}} \mathrm{dm}^{-3}$, respectively for the layers $0-0.2$ and $0.2-0.4 \mathrm{~m}$ and $31.7 \mathrm{~g} \mathrm{~kg}^{-1}$ of organic matter in the plowed layer of the soil (up to $0.2 \mathrm{~m}$ ). The determinations followed the methodologies proposed by Embrapa (2011a).

The rainfall in the experimental area and the temperature variation during the period of conduction of the experiment are presented in Figure 1 (Inmet, 2016).

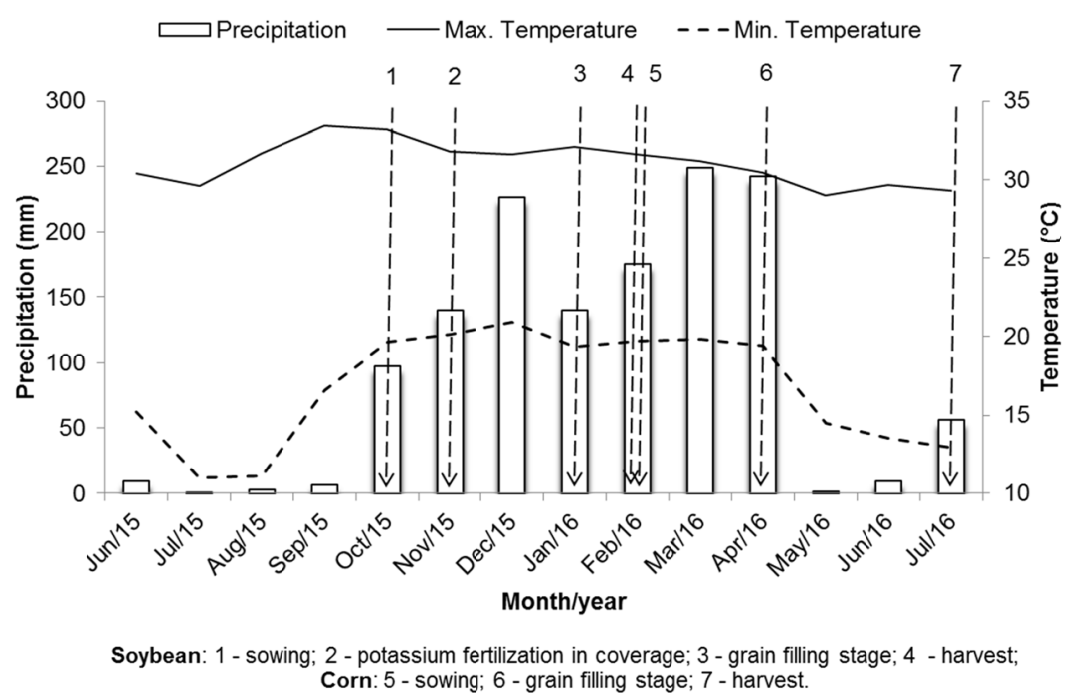

Figure 1. Rainfall (mm) and monthly temperature observed in the experimental area in Jataí, GO

Because of the decomposition of the remaining corn straw, the evaluation of $\mathrm{K}_{2} \mathrm{O}$ accumulation was continued in the period from September to December 2015, collecting up randomly in an area adjacent to the experiment, one $\mathrm{m}^{2}$ of Straw. Four samples were collected per sample date, which were dried in a forced circulation oven and analyzed according to the methodology proposed by Malavolta et al. (1997). 
The experimental design was in a randomized block design with four repetitions. The treatments consisted of a factorial of $5 \times 3$, the five potassium doses $\left(0,40,80,120\right.$ and $160 \mathrm{~kg} \mathrm{ha}^{-1}$ of $\left.\mathrm{K}_{2} \mathrm{O}\right)$ applied in three periods: i) $100 \%$ of the applied dose one day before sowing; (ii) $50 \%$ of the dose applied one day before sowing and the other $50 \%$ of the dose 30 days after sowing (DAS); iii) $100 \%$ of the applied dose 30 DAS, using potassium chloride $(\mathrm{KCl})$ as the source, with manual seed distributions without incorporation into the soybean crop.

The harvest was used to cultivate Anta 82RR (indeterminate growth), inoculated with nitrogen-fixing bacteria. In the pre-planting of the soybean were applied on the surface, without incorporation, $150 \mathrm{~kg} \mathrm{ha}^{-1}$ of MAP. The plots were composed of $25 \mathrm{~m}^{2}$ with spacing between rows of $0.50 \mathrm{~m}$ and population of 550 to 560 thousand plants/ha.

In the corn, the Pioneer P3646 intrasect corn hybrid. In pre-planting of corn, $55 \mathrm{~kg} \mathrm{ha}^{-1}$ of Monoammonium phosphate (MAP) and $150 \mathrm{~kg} \mathrm{ha}^{-1}$ of N-urea were applied to the surface, without incorporation, when the plants were in the stage of development V3 (Santos et al., 2014). The plots were composed of $25 \mathrm{~m}^{2}$ with line spacing of $0.80 \mathrm{~m}$ and population of 50 to 60 thousand plants/ha. For the corn was used the residual effect of the potassium fertilization carried out in the soybean crop. For both soybean and corn, phytosanitary treatments were carried out according to the farm's protocol.

During the flowering of the soybean crop (47 DAS), the dry mass of plants and leaf K content were evaluated according to the methodology described by Boaretto et al. (2009), collecting four random plants within the useful area of each plot. In the corn crop, on the occasion of the female flowering (91 DAS), the leaf K content was evaluated according to the method described by Silva (2009), it was also evaluated the stem diameter of four random plants in the useful area of each plot.

Harvesting of soybean and corn crops was carried out, respectively, at 105 and 158 DAS, manually in the useful area of each plot. In the corn, cob length, cob diameter and number of grains per cob were also evaluated using four random corn cobs per plot. Afterwards, grain yields, grain mass and $\mathrm{K}_{2} \mathrm{O}$ accumulation were determined in the grains of both crops, with moisture corrected at 13\% (MAPA, 2009).

Leaf and grain samples of soybean and corn were dried in a $60{ }^{\circ} \mathrm{C}$ oven and then minced in a grinding mil like Willey (20 mesh). Digestion was performed following procedures described by Malavolta et al. (1997), and the determination of the of $\mathrm{K}_{2} \mathrm{O}$ by flame photometry and accumulation of $\mathrm{K}_{2} \mathrm{O}$ calculated as a function of the dry matter of the evaluated parts.

The amount of $\mathrm{K}$ available in soil, $\mathrm{mg} \mathrm{dm}^{-3}$, were estimated considering the nutrient concentration, according to their final content after each culture in the sampled layers of 0.0-0.2 and 0.2-0.4 m depth.

The data were submitted to analysis of variance $(p<0.05)$ and when significant differences were found they were compared by the Scott-Knott test $(p<0.05)$ using Sisvar software (Ferreira, 2011) regression according to the doses of fertilizer applied.

\section{Results and Discussion}

The straw deposited on the soil establishes new criteria in the recommendation of agricultural fertilizers, mainly in relation to the management of the potassium fertilization. The straw of the soybean-corn succession in the experimental area was quantified and evaluated for the release of $\mathrm{K}$ (Figure 2A), it is possible to observe a large volume of cultural remains, above $9 \mathrm{Mg} \mathrm{ha}^{-1}$ at the time of the first evaluation. The decomposition of this straw occurred in a gradual way, decomposing $26 \%$ in the first 45 days, when the soybean was sown. In this initial period, straw yielded $62 \%$ of $\mathrm{K}$ (Figure $2 \mathrm{~B}$ ). 

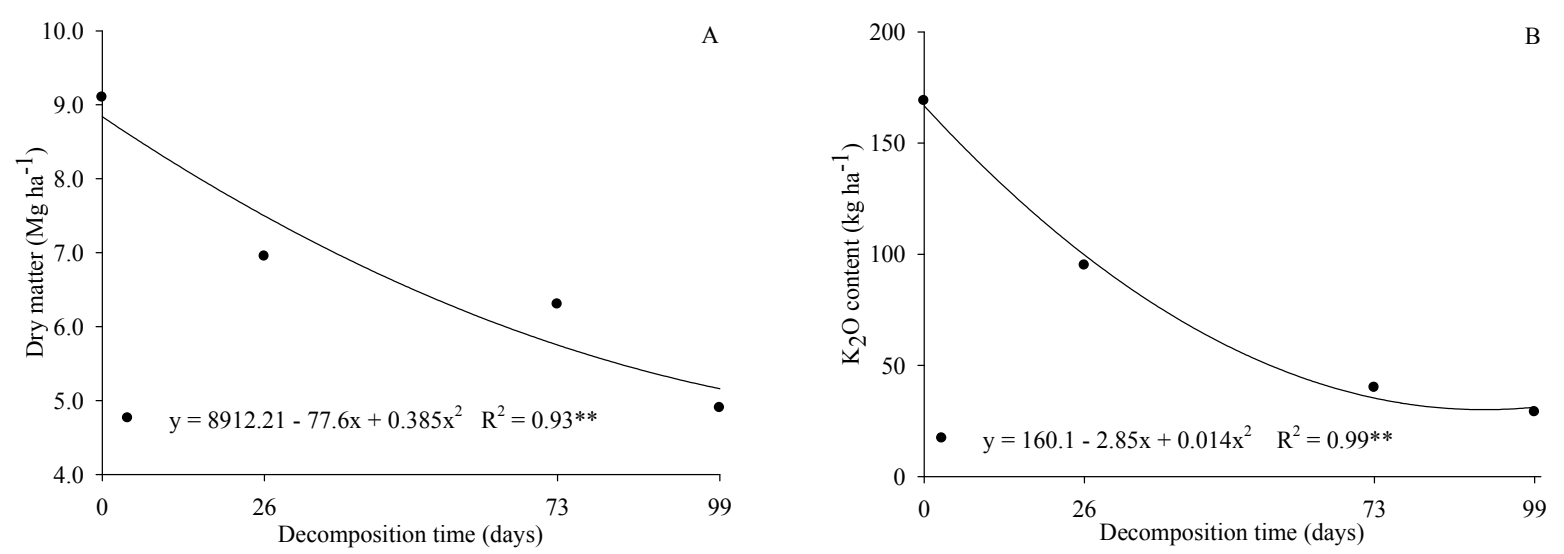

Figure 2. Dry matter (A) and $\mathrm{K}_{2} \mathrm{O}$ content (B) in the remaining corn straw cultivated in a typical clayey Oxisol with improved fertility in Jataí, GO

Note. ** Significant at 0.01 probability.

After sowing, the decomposing straw was able to supply more than $35 \mathrm{~kg} \mathrm{ha}^{-1}$ of $\mathrm{K}_{2} \mathrm{O}$, contributing with more than $25 \%$ of the $\mathrm{K}$ absorbed by the soybean crop (Embrapa, 2011b).This process is of great importance, since the release occurs continuously and uniformly, contributing to the absorption of the element by the crop and minimizing leach losses.

It is important to observe that the cultural remains of corn were able to release about $140 \mathrm{~kg} \mathrm{ha}^{-1}$ of $\mathrm{K}_{2} \mathrm{O}$, which according to Oliveira Júnior et al. (2013), represents $56 \%$ of the total extracted by the soybean, that is, if we do not consider possible losses of this nutrient due to adverse weather and soil conditions, the straw would be able to supply the need of the crop to the R4 stage, where the pods are fully developed $(>2.0 \mathrm{~cm})$ in one of the four upper nodes on the main stem.

According to Zobiole et al. (2012), the maximum uptake of K by the soybean occurs until the final stage of grain filling ( 76 to $100 \%$ granulation in one of the four upper nodes in the main stem), which corresponds to the 95 DAS. At this stage the culture requires about $2.5 \mathrm{~kg} \mathrm{ha}^{-1} \mathrm{day}^{-1}$ of $\mathrm{K}_{2} \mathrm{O}$. Concomitantly with the values obtained in the author's work and in the results obtained with the $\mathrm{K}_{2} \mathrm{O}$ release curve of this study, it can be considered that the corn straw is an important residual source for the soybean, because at 99 DAS it reached a value mean of 1.4 $\mathrm{kg} \mathrm{ha}^{-1}$ day $^{-1}$, partially satisfying the need for $\mathrm{K}_{2} \mathrm{O}$ for the crop.

This release is probably associated with senescence of plant tissues and the fact that $\mathrm{K}$ is not associated with any structural component of the plant (Marschner, 2012), which would cause the rapid release of this element into the soil. Similar results are reported in the literature. According to Borkert et al. (2003) and Foloni and Rosolem (2008), black oats and corn are cover species with a high capacity to recycle soil, mainly due to the high dry matter production, besides having a vigorous and deep root system, allowing to bring the $\mathrm{K}$ contained in the deeper layers of the soil.

Among the doses and application times evaluated, it is possible to observe that, with the application of $\mathrm{K}$ before sowing, soybean cultivation showed the best result at the highest dose, in the parceled application, the best result was obtained at a dose of $80 \mathrm{~kg} \mathrm{ha}^{-1}$ of $\mathrm{K}_{2} \mathrm{O}$, with production of 3.6 $\mathrm{Mg}$ ha $^{-1}$ (Figure 3A). 

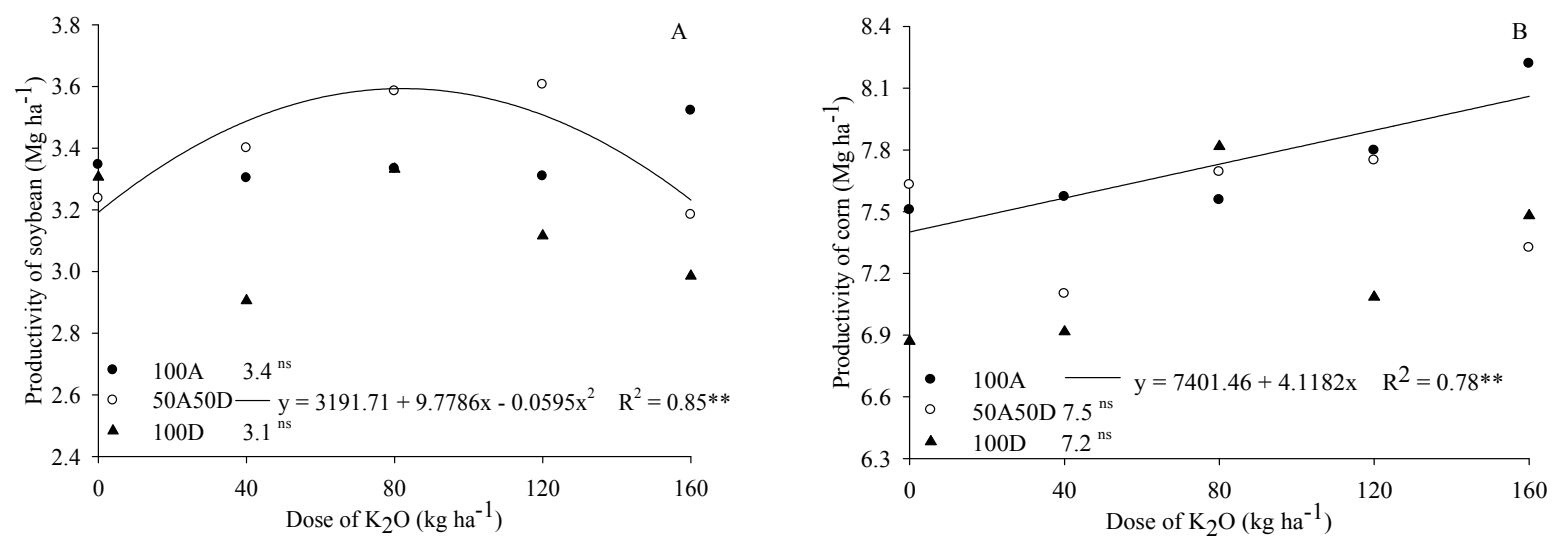

Figure 3. Productivity of soybean (A) and corn (B) as a function of $\mathrm{K}_{2} \mathrm{O}$ doses in a typical clayey Oxisol with improved fertility in Jataí, GO. 100A: dose applied before sowing; 50A50D: 50\% of the dose applied before sowing and 50\% in coverage; 100D: applied dose in coverage

Note. ${ }^{* *}$ Significant at 0.01 probability; ${ }^{\mathrm{ns}}=$ not significant.

Observing the values presented in Figure $3 \mathrm{~A}$, for the application of $\mathrm{K}$ before sowing, it can be noted that the increases observed under soybean yield were not significant to the increase in the doses of $\mathrm{K}_{2} \mathrm{O}$ applied to the soil, presenting an average value of $3.4 \mathrm{Mg} \mathrm{ha}^{-1}$. In Figure 3B it can be observed that the application of $160 \mathrm{~kg}$ $\mathrm{ha}^{-1}$ of $\mathrm{K}_{2} \mathrm{O}$ before sowing of soybean resulted in significant linear increases under corn yield of $7.9 \mathrm{Mg} \mathrm{ha}^{-1}$, a fact that can be explained by a possible the residual effect of $\mathrm{K}$ on the soil, when compared to other times of application and doses tested.

In a study by Pedroso Neto and Rezende (2005), the application of K to the plantation and parcels provided a productivity increase in the order of $15.38 \%\left(356 \mathrm{~kg} \mathrm{ha}^{-1}\right)$ and $13.26 \%\left(307 \mathrm{~kg} \mathrm{ha}^{-1}\right)$ in relation to the cover crop application in the soybean crop. It is worth mentioning that even obtaining the best results, the application of high doses of $\mathrm{KCl}\left(160 \mathrm{~kg} \mathrm{ha}^{-1}\right.$ of $\left.\mathrm{K}_{2} \mathrm{O}\right)$ may imply greater damage to the root growth of the seedlings, mainly due to its saline effect (Oliveira et al., 2008). According to Bernardi et al. (2009), the high salinity of some fertilizers, especially $\mathrm{KCl}$, impairs root growth and distribution, as well as the absorption of water and nutrients, because it reduces the osmotic potential near the rhizosphere, making it difficult to move the ions to the roots.

It is appropriate to report that the experimental area, for its fertility history, associated with amounts of $\mathrm{K}_{2} \mathrm{O}$ applied to the seeding of soybean and exported through the grains, was not enough to interfere significantly under the productivity of corn, as to the application in installments and in coverage. In this sense, it is likely that, during the succession of crops, these effects show themselves more pronounced.

Regarding the biomass parameters measured in soybean, no difference was observed in the dry mass of the aerial part and mass of a thousand grains, which presented a general average of $63.13 \mathrm{~g} \mathrm{plant}^{-1}$ and $127 \mathrm{~g}$, respectively. Leaf $\mathrm{K}$ content at the time of soybean bloom also did not differ between treatments, and its overall mean was $24.2 \mathrm{~g} \mathrm{~kg}^{-1}$. The accumulation of $\mathrm{K}_{2} \mathrm{O}$ in the soybean grains did not change with the $\mathrm{K}$ doses. After analyzing the causes of variation separately, a significant difference was observed for the time factor of application of $\mathrm{K}$ (Table 1). It is possible to observe that the parceled application of $\mathrm{K}$ in soybean promoted a lower accumulation of this nutrient in the grains, varying in $11.42 \%$ and $10.42 \%$ when compared to the applications before sowing and in coverage, respectively. 
Table 1. Accumulation of $\mathrm{K}_{2} \mathrm{O}$ in soybean and corn grains and mass of 100 grains of corn as a function of the application times in a typical clayey Oxisol with improved fertility in Jataí, GO

\begin{tabular}{|c|c|c|c|}
\hline \multirow[t]{2}{*}{ Application Seasons of Potassium } & \multicolumn{2}{|c|}{ Accumulation of $\mathrm{K}_{2} \mathrm{O}$ in the grains $\left(\mathrm{g} \mathrm{kg}^{-1}\right)$} & \multirow{2}{*}{ Mass of 100 grains (g) } \\
\hline & ---------- Soybean ---------- & 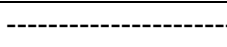 & \\
\hline $100 \mathrm{~A}$ & $18.59 \mathrm{a}$ & $42.1 \mathrm{a}$ & $34.9 \mathrm{~b}$ \\
\hline $50 \mathrm{~A} 50 \mathrm{D}$ & $16.42 \mathrm{~b}$ & $43.5 \mathrm{a}$ & $37.7 \mathrm{a}$ \\
\hline $100 \mathrm{D}$ & $18.33 \mathrm{a}$ & $39.9 \mathrm{~b}$ & $35.8 \mathrm{~b}$ \\
\hline C.V. $(\%)$ & 9.83 & 9.68 & 4.14 \\
\hline
\end{tabular}

Note. Means followed by the same letter in the column do not differ from each other to a 5\% probability by the Scott-Knott test; 100A: dose applied before sowing; 50A50D: 50\% of the dose applied before sowing and 50\% in coverage and 100D: dose applied in coverage.

On the other hand, to the application of $\mathrm{K}$ before sowing and in cover provided greater accumulation in the grains (18.59 and $18.33 \mathrm{~g} \mathrm{~kg}^{-1}$, respectively) even reaching a productivity average lower than the slip application. Possibly the initial high availability of potassium in the soil $\left(71 \mathrm{mg} \mathrm{dm}^{-3}\right)$, perhaps due to the adoption of the no-tillage system for more than 15 years, and the addition of $\mathrm{K}$ in a single dose, contributed to the high export of this nutrient by the plant. Therefore, regardless of the productivity levels reached by soybean crops, K export via grain harvest was influenced by the mode of application of potassium fertilizer.

According to Borkert et al. (2005), it is necessary to use potassium fertilization of about $36 \mathrm{~kg}$ of $\mathrm{K}_{2} \mathrm{O}$ to produce one ton of soybean grains. Thus, for the simulation effect from the results obtained in this study, it is estimated that 121,124 and $112 \mathrm{~kg} \mathrm{ha}^{-1}$ of $\mathrm{K}_{2} \mathrm{O}$ for the anticipated application to sowing, in installments and in cover, respectively, the average yields of grains obtained in each season of fertilizer application were calculated.

Still on the work of Borkert et al. (2005), it is argued that $60 \%$ of the $\mathrm{K}_{2} \mathrm{O}$ needed to produce one ton of soybean are exported via harvest. Considering the average productivity attained in this experiment, it is estimated that $\mathrm{K}$ exports correspond to 73,74 and $67 \mathrm{~kg} \mathrm{ha}^{-1}$ of $\mathrm{K}_{2} \mathrm{O}$ for the anticipated application to sowing, in installments and in coverage, respectively. The actual results of this study were 63,56 and $57 \mathrm{~kg} \mathrm{ha}^{-1}$ of $\mathrm{K}_{2} \mathrm{O}$, for the anticipated application to sowing, in installments and in cover, respectively (Table 1). This indicates that the perceled application, irrespective of the dose, favored lower export of $\mathrm{K}$ in the grains, even with production superior to the other times of fertilizer application. These results indicate that the $\mathrm{K}$ supply to the plants depends more on the newly added $\mathrm{K}$ than on the residual effect of potassium fertilization on the soil.

In the second crop it is possible to observe significant effect isolated for the application times factor of $\mathrm{K}$ for the variables accumulation of $\mathrm{K}_{2} \mathrm{O}$ and mass of 100 grains. For the accumulation of $\mathrm{K}_{2} \mathrm{O}$, it is noticed that the application after sowing of the soybean, independently of the dose, promoted a lower content in the corn kernels. However, the reduction of $5.2 \%$ and $8.3 \%$ in relation to the applications before sowing and plotting, respectively, reflect the low productivity obtained and consequently, a smaller increase in the mass of 100 grains (Table 1).

The main justification for low corn responses in the present experiment is related to climatic limitations. Situations of high temperatures and poor distribution of rainfall, such as those observed in the period between the development stages the tasseling and milk stage of corn (growth stage R3) (Figure 1), did not allow the crop to express its productive potential. At these stages, carbohydrate accumulation occurs in the grains and the lack of water can reduce the transport of photo-assimilates, leading to lower unit grain weight and low productivity (Venturoso et al., 2009a).

The absence of responses to the variation in potassium fertilization for the variables $\mathrm{K}$ content in the leaf at the time of flowering and the mass of one thousand soybean grains seems to have confirmed the $\mathrm{K}$ buffering in the soil, which did not present interaction and/or factor effect isolated between the sources of variation analyzed, with average values of $24.23 \mathrm{~g} \mathrm{~kg}^{-1}$ and $127.66 \mathrm{~g}$, respectively.

Observing the values presented in Table 1 for leaf $\mathrm{K}$ content in plants, it can be noted that even without significant differences, it reflects a higher absorption of this nutrient in the soil, once, the levels are classified as high in the interpretation table for the culture. This higher accumulation of $\mathrm{K}$ in plants can be explained by the fact that, under conditions of high initial availability of $\mathrm{K}$ in the soil $\left(71 \mathrm{mg} \mathrm{dm}^{-3}\right)$, plants absorb more than their metabolic need, which is accumulated in plant cell organelles (as in chloroplasts, mitochondria, and especially vacuoles), characterizing "luxury consumption" (Gommers et al., 2005). The increase of K accumulation in plants due to the residual effect and/or potassium fertilization is usually reported in the literature (Kaminski et al., 2007; Fraga et al., 2009). 
Malavolta et al. (1997) established as ideal for the optimal development of plants concentrations between 17 and $25 \mathrm{~g} \mathrm{~kg}^{-1}$ of $\mathrm{K}$ in soybean leaves and between 17 and $35 \mathrm{~g} \mathrm{~kg}^{-1}$ in corn leaves.

The mass of a thousand grains is an intrinsic characteristic of the corn. However, the availability of potassium in the soil did not affect the weight of the grains, so there was no difference between the averages obtained (Table 1). On the other hand, in soils with low content the mass of a thousand grains can have a positive answer. Venturoso et al. (2009b), observed that the weight of 100 grains presented a positive response to the potassium doses, and a marked increase was observed up to the dose of $110 \mathrm{~kg} \mathrm{ha}^{-1}$ of $\mathrm{K}_{2} \mathrm{O}$ applied to soybean sowing.

Corn is less sensitive to differences in $\mathrm{K}$ availability in soil, presenting less variation for desirable agronomic characteristics. The variables: cob length, cob diameter, stem diameter at flowering, leaf $\mathrm{K}$ content and number of grains per cob did not differ according to application times and potassium doses, with mean values of 15.67 $\mathrm{cm}, 4.83 \mathrm{~cm}, 2.00 \mathrm{~cm}, 27.62 \mathrm{~g} \mathrm{~kg}^{-1}$ and 614 grains/cob, respectively. Thus, showing behavior independent of the analyzed factors.

However, it is interesting to note that the results allow us to infer that the use of potassium fertilizers in order to increase the stock of $\mathrm{K}$ in the soil, not fully justified, as there are also depletion of these forms by luxury absorption of the plants, as well as high leaching losses (Werle et al., 2008).

The $\mathrm{K}$ contents available in the soil profile as a function of potassium fertilizer application are shown in Figure 4.
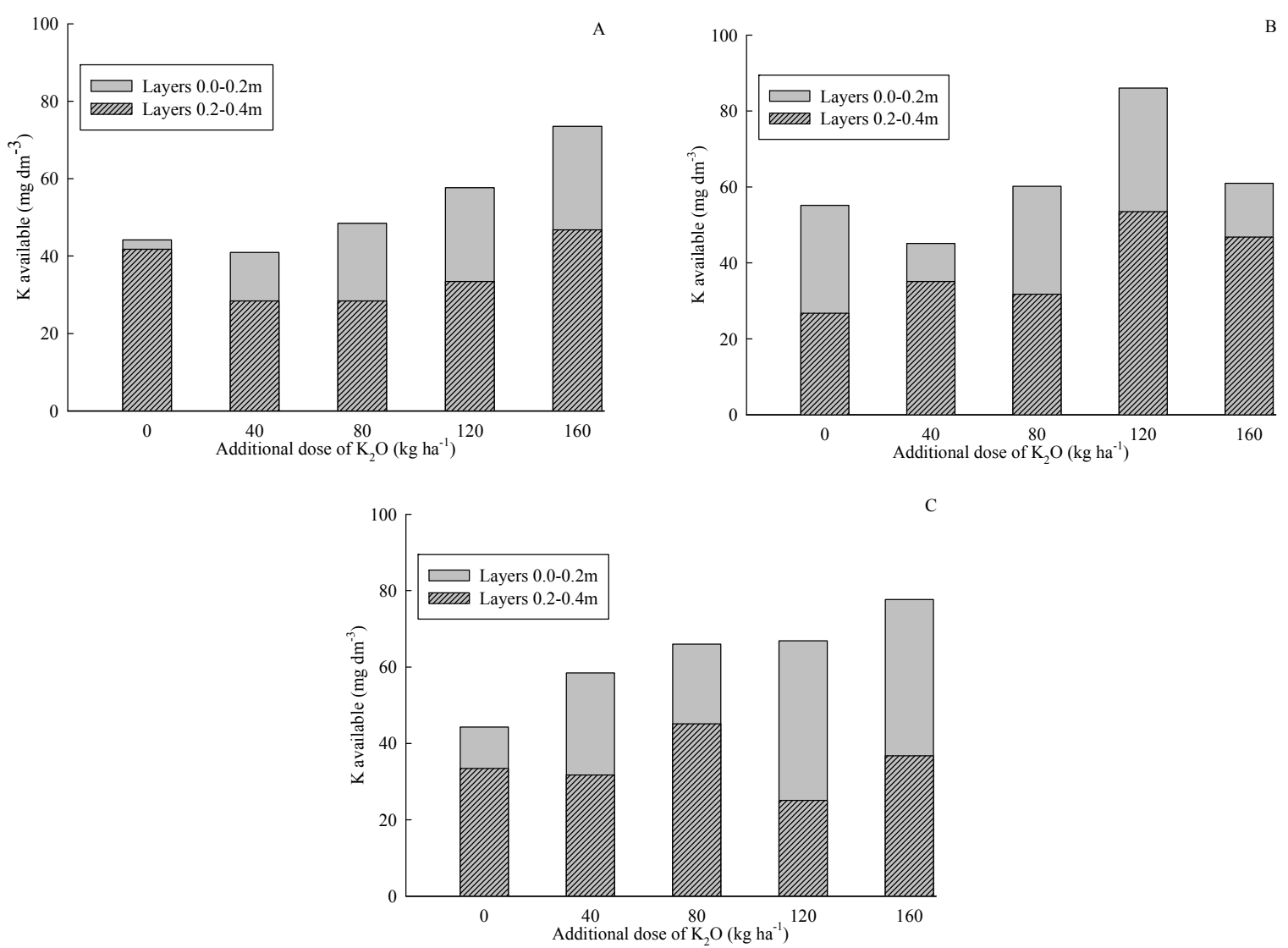

Figure 4. $\mathrm{K}$ available in the soil after soybean cultivation as a function of $\mathrm{K}_{2} \mathrm{O}$ doses in a typical clayey Oxisol with improved fertility in Jataí, GO. A: dose applied before sowing (100A); B: 50\% of the dose applied before sowing and 50\% in coverage (50A50D) and C: dose applied in coverage (100D)

As regards the distribution of $\mathrm{K}$ levels in the soil profile after soybean harvest, lower levels of nutrient in depth (0.2-0.4 m) were observed, forming decreasing gradients of $\mathrm{K}$ concentration from the surface of the soil, mainly for the total applications of $\mathrm{K}_{2} \mathrm{O}$ in sowing and cover. The absence of soil stirring in the no-tillage system, together with the maintenance of vegetal residues on the surface and the application of fertilizers, results in the 
accumulation of organic matter and nutrients in the soil surface layer. The organic matter is responsible for a great part (up to $80 \%$ ) of the CTC of the tropical soils (Briedis et al., 2012b).

Potassium fertilization of $120 \mathrm{~kg} \mathrm{ha}^{-1}$ of $\mathrm{K}_{2} \mathrm{O}$ applied in installments in the soybean crop (50\% of the applied dose before sowing and $50 \%$ in the cover) increased the levels of $\mathrm{K}$ available in 17.5 and $15.8 \%$ compared to their initial levels in the soil, in the layers of 0.0-0.2 and 0.2-0.4 m, respectively (Figure 4B). It is noted that in other periods of fertilizer application were necessary to apply $160 \mathrm{~kg} \mathrm{ha}^{-1} \mathrm{~K}_{2} \mathrm{O}$ to reach at least the initial content of $\mathrm{K}$ in the soil after cultivation of soybean (Figures $4 \mathrm{~A}$ and $4 \mathrm{C}$ ).

In a study conducted over three years in a Oxisol with $120 \mathrm{~g} \mathrm{~kg}^{-1}$ of clay in São Manoel (SP), Rosolem and Nakagawa (2001) reported an increase in the rate of leaching of $\mathrm{K}$ in the profile when doses above $80 \mathrm{~kg} \mathrm{ha}^{-1}$ of $\mathrm{K}_{2} \mathrm{O}$ per year, regardless of the fertilizer application method. This movement of $\mathrm{K}$ in the soil profile to depths below those explored by the roots, especially in the higher doses, indicates that the losses of $\mathrm{K}$ by leaching can be significant in medium textured soils. Obviously, these assumptions need to be tested for any conclusions to be drawn.

In corn, although the soil presents an adequate initial fertility condition, a negative balance of potassium in the soil is observed. However, it can be stated that the depletion of $\mathrm{K}$ is directly related to the management method adopted, since potassium fertilization was only carried out in the summer crop. In other words, the K output of the system was superior to the fertilizer input at all times and times of application, except for the treatment with $120 \mathrm{~kg} \mathrm{ha}^{-1} \mathrm{~K}_{2} \mathrm{O}$ applied to the soil in a parceled manner, where $\mathrm{K}$ content increased by $4.4 \mathrm{mg} \mathrm{dm}^{-3}$ (Figure 5 ).
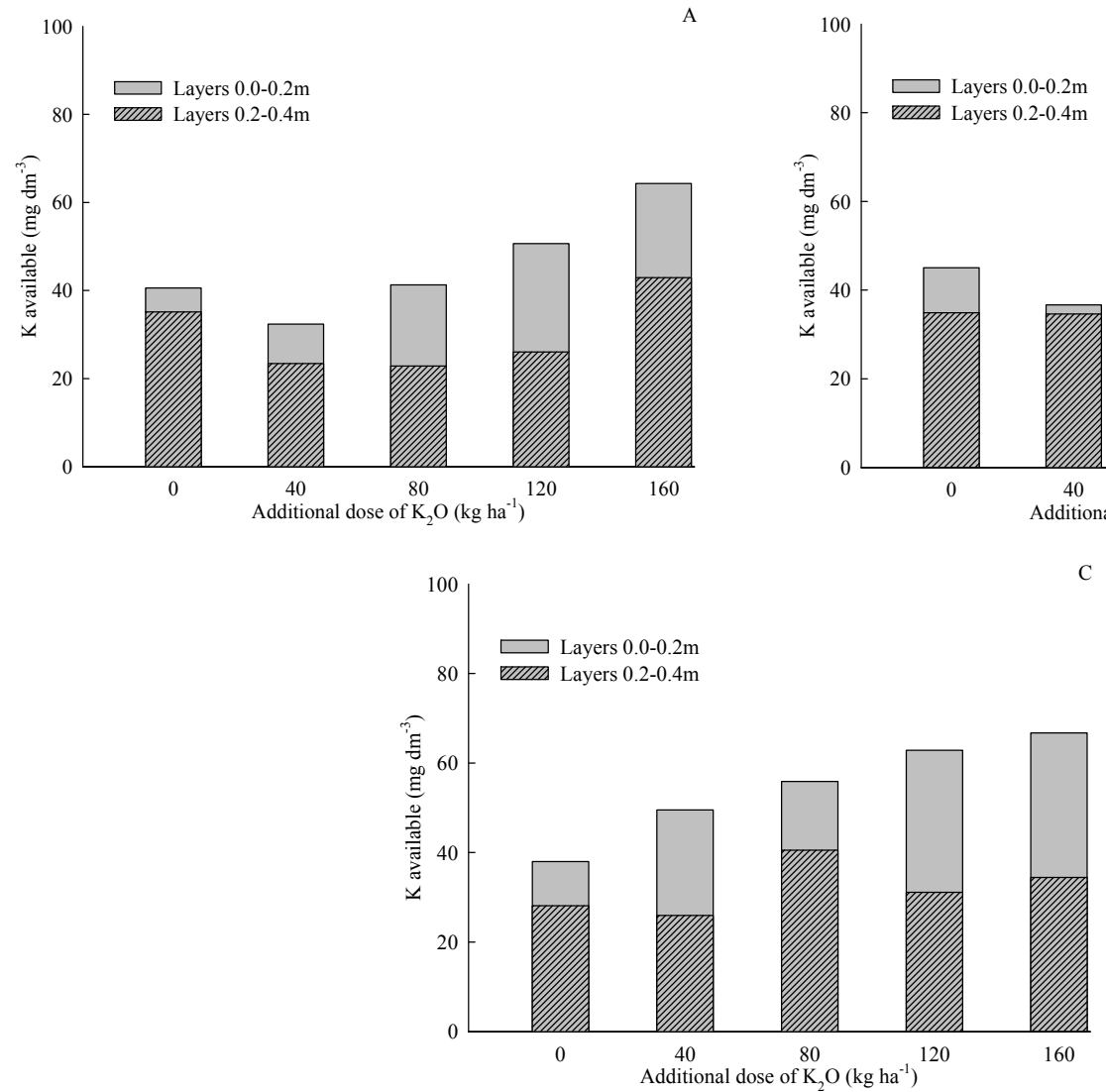

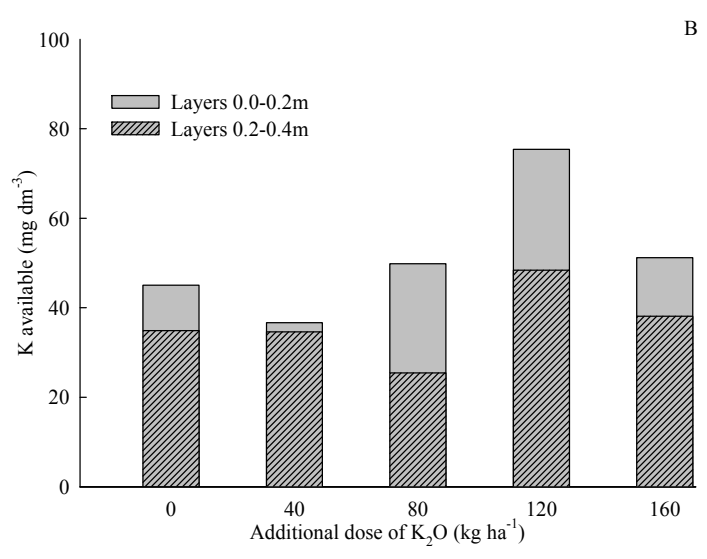

Figure 5. $\mathrm{K}$ available in the soil after corn cultivation as a function of the $\mathrm{K}_{2} \mathrm{O}$ doses in a typical clayey Oxisol with improved fertility in Jataí, GO. A: dose applied before sowing (100A); B: 50\% of the dose applied before sowing and 50\% in coverage (50A50D) and C: dose applied in coverage (100D)

Considering all treatments, it is possible to observe that the available $\mathrm{K}$ levels in the layer of 0.0-0.2 and 0.2-0.4 $\mathrm{m}$ of depth in the soil ranged from 32.38 to $66.75 \mathrm{mg} \mathrm{dm}^{-3}$ and from 22.89 to $42.94 \mathrm{mg} \mathrm{dm}^{-3}$, respectively. According to the limits of interpretation of soil $\mathrm{K}$ levels established for the main annual crops, these values fall into the "low" and "medium" availability classes (Werle et al., 2008). However, it was verified that the 
application of $120 \mathrm{~kg} \mathrm{ha}^{-1}$ of $\mathrm{K}_{2} \mathrm{O}$ was sufficient to meet the demand of the soybean and corn crop and maintain the $\mathrm{K}$ content in the soil close to the critical level (Rosolem \& Calonego, 2013).

In the present work, it was possible to observe a decrease in the available $\mathrm{K}$ content of the soil at the end of the experiment, due to the strategy of fertilizing only the summer crop and the exhaustion of this form of $\mathrm{K}$ was due to its overuse to supply the plants demand, as verified in the accumulation of $\mathrm{K}_{2} \mathrm{O}$ in the grains, or eventual losses of the system by leaching and erosion.

It is observed that the application of doses lower than $80 \mathrm{~kg} \mathrm{ha}^{-1}$ of $\mathrm{K}_{2} \mathrm{O}$ resulted in a reduction in the amount of $\mathrm{K}$ available in the soil profile by up to $21.3 \%$ in the $0.0-0.2 \mathrm{~m}$ layer of depth, regardless of the fertilizer application time. When there was no addition of $\mathrm{K}$ in the soil, the reduction in the average amount of $\mathrm{K}$ available was $41.2 \mathrm{mg} \mathrm{dm}^{-3}$ of $\mathrm{K} \mathrm{n}$ the layer of $0.0-0.2 \mathrm{~m}$ of depth. Therefore, it is evident that, despite the non-fertilization treatment, good yields were obtained for both soybean and corn, soil K content decreased by an average of $42 \%$ in only one crop year.

It is evident that in order to increase the efficiency of fertilizer use in improved fertility soils, it is suggested to reduce the amount to be applied in the less responsive crop, in the case of the present study, the soybean, and intensify the fertilization of the more responsive crop, in this case, corn. Other authors have also reported differentiated behavior between the two cultures and suggested similar management (Benites et al., 2010).

\section{Conclusion}

The best performance of soybean, considering grain yield, was obtained with the parceled application of $80 \mathrm{~kg}$ $\mathrm{ha}^{-1}$ of $\mathrm{K}_{2} \mathrm{O}$, with production of $3.6 \mathrm{Mg} \mathrm{ha}^{-1}$.

The highest corn production was obtained with the anticipated application of $160 \mathrm{~kg} \mathrm{ha}^{-1}$ of $\mathrm{K}_{2} \mathrm{O}$ in soybean.

In the management of potassium fertilization in improved fertility areas under the soybean-corn succession, the parceled application of $120 \mathrm{~kg} \mathrm{ha}^{-1}$ of $\mathrm{K}_{2} \mathrm{O}$ kept the available $\mathrm{K}$ reserve in the soil constant when compared to its initial content.

\section{Acknowledgements}

The authors extend thanks to Universidade Federal de Goiás, CAPES and a farm Irmãos Gazarini in Jataí-GO, for their financial support, which was indispensable to the execution of this study.

\section{References}

Benites, V. M., Polidoro, J. C., \& Resende, A. V. (2010). Oportunidades para a inovação tecnológica no setor de fertilizantes no Brasil. Boletim Informativo da Sociedade Brasileira de Ciência do Solo, 35(3), 18-21.

Bernardi, A. C. C., Oliveira Júnior, J. P., Leandro, W. M., Mesquita, T. G. da Silva., Freitas, P. L. de, \& Carvalho, M. C. da S. (2009). Doses e formas de aplicação da adubação potássica na rotação soja, milheto e algodão em sistema plantio direto. Pesquisa Agropecuária Tropical, 39(2), 158-167.

Boaretto, A. E., Raij, B. Van, Silva, F. C. da, Chitolina, J. C., Tedesco, M. J., \& Carmo, C. A. F. S. do. (2009). Amostragem, acondicionamento e preparo de amostras de plantas para análise química. In F. C. Silva (Ed.), Manual de análises químicas de solos, plantas e fertilizantes. (pp. 59-85).

Borkert, C. M., Castro, C. de, Oliveira, F. A. de, Klepker, D., \& Oliveira Júnior, A. de. (2005). O potássio na cultura da soja. In T. Yamada, \& T. L. Roberts (Eds.). Potássio na agricultura brasileira, 1, 671-722.

Borkert, C. M., Gaudêncio, C. A. de, Pereira, J. E., Pereira, L. R., \& Oliveira Júnior, A. de. (2003). Nutrientes minerais na biomassa da parte aérea em culturas de cobertura de solo. Pesquisa Agropecuária Brasileira, 38(1), 143-153. https://doi.org/10.1590/S0100-204X2003000100019

Briedis, C., Sá, J. C. M., Caires, E. F., Navarro, J. F., Inagaki, T. M., \& Ferreira, A. O. (2012). Carbono do solo e atributos de fertilidade em resposta à calagem superficial em plantio direto. Pesquisa Agropecuária Brasileira, 47, 1007-1014. https://doi.org/10.1590/S0100-204X2012000700018

Calonego, J. C., Gil, F. C., Rocco, V. F., \& Santos, E. A. (2012). Persistência e liberação de nutrientes da palha de milho, braquiária e labe-labe. Bioscience Journal, 28(5), 770-781.

CONAB (Companhia Nacional de Abastecimento). (2016a). Acompanhamento da safra brasileira de grãos, Safra 2015/16 (Sétimo levantamento, 7, pp. 1-158).

CONAB (Companhia Nacional de Abastecimento). (2017). Acompanhamento da safra brasileira de grãos-2016/17 (Acompanhamento da safra brasileira de grãos 4, p. 9). Retrieved from http://www.conab. gov.br/OlalaCMS/uploads/arquivos/17_06_08_09_02_48_boletim_graos_junho_2017.pdf 
EMBRAPA (Empresa Brasileira de Pesquisa Agropecuária). (2011a). Manual de métodos de análise de solo (p. 230). Dados eletrônicos.

EMBRAPA (Empresa Brasileira de Pesquisa Agropecuária). (2011b). Tecnologias de produção de soja: Região central do Brasil 2012 e 2013. Sistemas de Produção, 15, 261.

Fancelli, A. L., \& Tsumanuma, G. M. (2006). Nitrogênio e enxofre nas culturas de milho e feijão. In T. Yamada, S. R. S. Abdalla, \& G. C. Vitti (Eds.), Nitrogênio e enxofre na agricultura brasileira (pp. 445-486). IPNI, Brasil.

Ferreira, D. F. (2011). Sisvar: A computer statistical analysis system. Ciência e Agrotecnologia, 35(6), 1039-1042. https://doi.org/10.1590/S1413-70542011000600001

Foloni, J. S. S., \& Rosolem, C. A. (2008). Produtividade e acúmulo de potássio na soja em função da antecipação da adubação potássica no sistema plantio direto. Revista Brasileira de Ciência do Solo, 32, 1549-1561. https://doi.org/10.1590/S0100-06832008000400019

Fraga, T. I., Genro Junior, S. A., Inda, A. V., \& Anghinoni, I. (2009). Suprimento de potássio e mineralogia de solos de várzea sob cultivos sucessivos de arroz irrigado. Revista Brasileira de Ciência do Solo, 33, 497-506. https://doi.org/10.1590/S0100-06832009000300003

Gommers, A., Thiry, Y., \& Delvaux, B. (2005). Rhizospheric mobilization and plant uptake of radiocesium from weathered soils: I. Influence of potassium depletion. Journal of Environmental Quality, 34(6), $2167-2173$. https://doi.org/10.2134/jeq2004.0406

Guareschi, R. F., Gazolla, P. R., Souchie, E. L., \& Rocha, A. C da. (2008). Adubação fosfatada e potássica na semeadura e a lanço antecipada na cultura da soja cultivada em solo de Cerrado. Semina: Ciências Agrárias, 29(4), 769-774. https://doi.org/10.5433/1679-0359.2008v29n4p769

INMET (Instituto Nacional de Metereologia). (2014). Dados históricos da Estação JATAÍ-GO (OMM: 86752). Retrieved from http://www.inmet.gov.br/portal/index.php?r=bdmep/bdmep

Kaminski, J., Brunetto, G., Moterle, D., \& Rheinheimer, D. dos S. (2007). Depleção de formas de potássio do solo afetada por cultivos sucessivos. Revista Brasileira de Ciência do Solo, 31(5), 1003-1010. https://doi.org/10.1590/S0100-06832007000500017

Malavolta, E., Vitti, G. C., \& Oliveira, S. A. (1997). Avaliação do estado nutricional das plantas: Princípios e aplicações (p. 319).

MAPA (Ministério da Agricultura, Pecuária e Abastecimento). (2009). Regras para Análise de Sementes (p. 395). Brasília, DF: Mapa/ACS.

Marschner, P. (2012). Mineral nutrition of higher plants (3rd ed., p. 672). London: Academic Press. https://doi.org/10.1016/B978-0-12-384905-2.00015-7

Oliveira Junior, A. de, Castro, C. de, Oliveira, F. A. de, \& Jordão, L. T. (2013). Adubação potássica da soja: cuidados no balanço de nutrientes. Informações Agronômicas, 143(1), 3-10.

Oliveira, F. A., Castro, C., Sfredo, G. J., Klepker, D., \& Oliveira Junior, A. (2008). Fertilidade do solo e nutrição mineral da soja (Circular Técnica 62). Londrina: Embrapa Soja.

Pauletti, V., Serrat, B. M., Motta, A. C. M., Favaretto, N., \& Anjos, A. dos. (2010). Yield response to fertilization strategies in no-tillage soybean, corn and common bean crops. Brazilian Archives of Biology and Technology, 53(3), 563-574. https://doi.org/10.1590/S1516-89132010000300009

Pedroso Neto, J. C., \& Rezende, P. M. (2005). Doses de modos de aplicação de potássio na produtividade de grãos e qualidade de sementes de soja (Glycine max (L.), Merrill). FAZU em Revista, 1(2), 27-36.

Resende, A. V. de, Coelho, A. M., Santos, F. C. dos, \& Lacerda, J. J. de J. (2012). Fertilidade do solo e manejo da adubação NPK para alta produtividade de milho no Brasil Central (Circular Técnica 181). Embrapa Milho e Sorgo.

Rosolem, C. A., \& Calonego, J. C. (2013). Phosphorus and potassium budget in the soil-plant system in crop rotations under no-till. Soil and Tillage Research, 126, 127-133. https://doi.org/10.1016/j.still.2012.08.003

Rosolem, C. A., \& Nakagawa, J. (2001). Residual and annual potassic fertilization for soybeans. Nutrient Cycling in Agroecosystems, 59(2), 143-149. https://doi.org/10.1023/A:1017555023168

Santos, H. G., Almeida, J. A. de, Anjos, L. H. C. dos, Coelho, M. R., Jacomine, P. K. T., Lumbreras, J. F., \& Oliveira, V. A. de. (2013). Sistema brasileiro de classificação de solos (p. 353). Embrapa Solos. 
Santos, H. P., Santos, R. S., Pires, J., Lampert, E. A., Vargas, A. M., \& Verdi, A. C. (2014). Rendimento de grãos e características agronômicas de soja em função de sistemas de rotação de culturas. Bragantia, 73(3), 263-273. https://doi.org/10.1590/1678-4499.0136

Silva, F. C. da. (2009). Manual de análises químicas de solos, plantas e fertilizantes (2nd ed., p. 627). Brasília: Embrapa Informação Tecnológica.

Sousa, D. M. G., \& Lobato, E. (2004a). Calagem e adubação para culturas anuais e semiperenes. In D. M. Sousa, \& G. Lobato (Eds.), Cerrado: correção do solo e adubação (Vol. 2, pp. 283-315).

USDA (United States Department of Agriculture). (2016a). Grain: World Markets and Trade (pp. 1-56). Foreign Agricultural Service-USDA, Office of Global Analysis.

Venturoso, L. R., Bergamim, A. C., Valadão Júnior, D. D., Lima, W. A., Oliveira, W. B., Schlindwein, J. A., Caron, B. O., \& Schimidt, D. (2009b). Avaliação de duas cultivares de soja sob diferentes doses de potássio, no município de Rolim de Moura, RO. Agrarian, 2(4), 17-29.

Venturoso, L. R., Caron, B. O., Schimidt, D., Bergamin, A. C., Valadão Junior, D. D., \& Jakelaitis, A. (2009a). Efeito da época de semeadura sobre caracteres agronômicos em cultivares de soja em Rolim de Moura-RO. Bioscience Journal, 25(4), 73-81.

Werle, R., Garcia, R. A., \& Rosolem, C. A. (2008). Lixiviação de potássio em função da textura e da disponibilidade do nutriente no solo. Revista Brasileira de Ciência do Solo, 32(6), 2297-2305. https://doi.org/10.1590/S0100-06832008000600009

Zobiole, L. H. S., Oliveira Júnior, R. S., Constantin, J., Oliveira Júnior, A., Castro, C., Oliveira, F. A., ... Romagnoli, L. M. (2012). Acúmulo de nutrientes em soja convencional e soja RR em diferentes tipos de controle de planta daninha. Planta Daninha, 30(1), 75-85. https://doi.org/10.1590/S0100-83582012000 100009

\section{Copyrights}

Copyright for this article is retained by the author(s), with first publication rights granted to the journal.

This is an open-access article distributed under the terms and conditions of the Creative Commons Attribution license (http://creativecommons.org/licenses/by/4.0/). 